\begin{tabular}{lllllll} 
O P E R A T I O N S R E S E A R C H A N D D E C I S I O N S \\
\hline No. 3
\end{tabular}

DOI: $10.37190 /$ ord210302

\title{
INTERNET OF THINGS IN THE ACCOUNTING FIELD. BENEFITS AND CHALLENGES
}

\author{
ANNA KARMAŃSKA* \\ Department of Business Informatics and International Accounting, \\ University of Economics in Katowice, ul. 1 Maja 50, 40-287 Katowice, Poland
}

\begin{abstract}
The main objective of this paper is to identify the benefits and challenges of the Internet of Things (IoT) application in the accounting field of organisations. The study adopts a questionnaire and an interview technique in a company from the road transport sector. The questionnaire research sample includes 151 accounting practitioners and students. Data are collected through the use of an online survey. A principal axis factor analysis with the Promax rotation is conducted to assess the underlying structure for the items of the questionnaire. The research outcomes indicate that, in the opinion of accountants and students, the IoT adoption enables the organisation to perform enhanced reporting analysis based on a large amount of data gained through sensors (mean $=3.98)$, access to data through cloud computing (3.97), and accounting process automation (3.95). From the point of view of managers, the most important benefit is the increase in employee productivity and asset management. The respondents indicate the following aspects as challenges: the creation of infrastructure for the adoption of new technology, which accounted for $40.22 \%$ of the variance, and cyber security, loss of privacy $(7.23 \%$ of the explained variance). The findings reveal benefits and challenges for IoT adoption and could support managers in deploying new technology in their organisations. The research limitation concerns the fact that this study focuses on respondents from Poland.
\end{abstract}

Keywords: Internet of Things, accounting, Industry 4.0

\section{Introduction}

The Internet of Things (IoT), as cutting-edge technology, is gaining significant momentum and shows immense potential to modernise every model of business. The IoT is defined as a network of dedicated physical objects (things) that contain embedded technology to sense or interact with their internal state or the external environment [1]. This is a paradigm where objects can be equipped with identifying, sensing, networking,

*Email address: anna.karmanska@uekat.pl

Received 29 November 2020, accepted 2 July 2021 
and processing capabilities that allow them to communicate with one another as well as with other devices and services over the Internet to accomplish objectives [2]. Chen et al. indicate the three unique features of IoT, namely: extreme heterogeneity, a massive number of devices, and unpredictable dynamics partially due to human interaction [3]. The notion was first coined by Kevin Ashton in a presentation that he made at Procter \& Gamble in 1999 [4]. He said the Internet of Things has the potential to change the world, just as the Internet did. Maybe even more so [4]. Some companies (for example Cisco) instead of IoT use the notion of IoE (Internet of Everything) as it connects four components: people, process, data, and things.

IoT enables billions of physical devices around the world connected to the Internet to collect, share data, and coordinate decisions. By the end of 2018, according to the statistical data, there were circa about 22 billion connected devices around the world, but forecasts suggest that around 50 billion devices will be in use by 2030 [5].

The main objective of this study is to identify the benefits and challenges of IoT application in the accounting field of organisations. The paper focuses on addressing the following research question: What are the benefits and challenges of IoT adoption for companies in the accounting field? According to the literature review, there is still an existing gap in the academic papers on this topic. The literature search, which was performed with the terms Internet of Things and accounting in bibliographic databases: Emerald Management and the ISI Web of Knowledge, clearly confirms the research gap.

The paper reads as follows: Section 1 is an introduction, the literature review is presented in Section 2. The methodology used in this research and the results are described in Section 3. Finally, conclusions and recommendations for future research are drawn in Section 4.

\section{Literature review}

The IoT technology is inextricably linked with the Industry 4.0 concept, which is also called the Second Machine Age. The umbrella term refers to further development, a fourth industrial revolution and was introduced as Industrie 4.0 - a German-government-sponsored vision for advanced manufacturing [7].

Industry 4.0 is based on the horizontal and vertical integration of various IT systems [10]. Horizontal integration refers to different stages of manufacturing and business planning processes that involve an exchange of materials, energy, and information both within an organisation and between different companies (value networks), whereas vertical integration takes place on different hierarchical levels [10].

IoT and cyber-physical systems (CPS) are the main technological building blocks for Industry 4.0 [8]. Culot et al. analyse almost 100 definitions of Industry 4.0 and re- 
lated concepts such as smart manufacturing, digital transformation, and the fourth industrial revolution [9]. The review of academic publications has been complemented by a selection of the most influential non-academic sources: governmental bodies and consulting providers. The authors found that IoT was the most common key enabling technology as it was mentioned in 70 academic definitions and 14 non-academic definitions. Cyber-physical systems ranked second (56 academic and 7 non-academic publications).

IoT is a technology of the future. EY conducted surveys of employees in 596 big Polish enterprises who were asked which of the new technologies based on IT solutions would have the greatest impact on their industry in the next 5 years. The respondents indicated: artificial intelligence (66\%), robotic process automation (RPA) (54\%), cloud computing (45\%), big data (33\%), IoT (31\%), 3D print (25\%), blockchain $(24 \%)$, and $5 \mathrm{G}(18 \%)$ [13]. However, IoT cannot be analysed in isolation from other technologies, because they are interdependent [14] and enterprises usually implement complex solutions based on many technologies.

The basic model of IoT consists of three-layer architecture: application, network, and perception [11]. The perception layer constitutes of:

- identifiers which identify the source of data (e.g., sensors, devices),

- sensors that measure, collect or generate data such as location, temperature, weight, vibration, motion,

- capable actuators, based on sensor data, to move or control a mechanism enabling the automation of tasks, for example opening a valve,

- video cameras $[4,12]$.

The perception layer collects and transfers data to the network layer in which transmitters and receivers, gateways, routers, switches are used to broadcast and receive messages. The data are transferred using the following technologies: RFID (radio frequency identification), WiFi, Bluetooth low energy, infrared, cellular (3G, 4G, 5G). In the application layer, computer chips process the data within the device to provide requested services. The application layer includes the key management software functions to enable the overall management of IoT devices [4].

The concept of Industry 4.0 has been adopted in different industry sectors. An example of IoT technology being used in urban architecture can be a smart city Songdo in South Korea. This is one of the first urban areas to be fully equipped and wired, which functions similarly as a living organism - it grows, mutates, and adapts to changing circumstances. Its infrastructure contains sensors to monitor and regulate everything from building temperatures to energy consumption, and from traffic flow to street lights, its residents interact with city monitoring systems via personalised digital devices [15].

The extension of IoT in industrial sectors - the industrial internet of things (IIoT) is promoted by $90 \%$ of companies around the world for attaining future goals [16]. IoT is also the main driver of Logistics 4.0 as it influences all tasks of logistics: incoming, internal, outgoing, and flows of material. According to the literature on Logistics 4.0 
reviewed by Winkelhaus and Grosse [8], $45 \%$ of the sampled articles mentioned IoT as the leading technology.

The application of IoT is of particular importance in fiscal policy because it influences the size and stability of tax inflows. An example can be online cash registers which were implemented in Poland [17]. An online cash register sends details of each recorded transaction directly to the central IT system - the Central Repository of Cash Registers, including details necessary to identify: the amount of taxable base and VAT, tax rates, type of goods or services, exact time of recording sales. The system connects with the repository every two hours without the user's knowledge, but the repository can also change this schedule. The online cash registers will replace traditional solutions and force more reliable sales records. And finally, IoT is used in Accounting 4.0, which can be defined as a conceptual framework for newly designed accounting processes in terms of emerging technologies [18].

The accounting information system accepts transactions as inputs which are next converted through various processes into financial information [20]. Thanks to IoT, most of the transactions could be processed automatically without a human being involved. Both international and local accounting standards require that financial information must be relevant and provide a faithful representation [21], true and fair view [22]. Using IoT has a positive effect on all the four qualitative characteristics of financial information [21] such as comparability, verifiability, timeliness, and understandability.

IoT yields many benefits for all types of organisations but like other technology adoptions also introduces unforeseen risks and requires substantial organisational transformations [19]. The literature on IoT benefits in the accounting field is very limited. Most of the academic papers address potential benefits and challenges associated with IoT in general business operations. For instance, based on the survey with 87 participants from six continents, Haddud et. al [23] analyse the benefits and challenges of IoT in organisations. The authors indicate that the top five potential benefits likely to be gained from the adoption of IoT by an individual organisation were: more transparency and visibility of information and material flows, improvement in product tracking, better control and management of inventories, improved integration of internal business processes, development of operational efficiency. The benefit categories can be summarised as: the capability to provide timely information for decision making and greater response times, automation of decision making, improved planning, reduction of operational costs, new revenue streams, better communication with clients. On the other hand, the top five potential challenges were: device and network security risks and vulnerabilities, lack of clear comprehension of IoT benefits, recruitment of supporting staff with the right skills and knowledge, risks associated with implementation of new business model, technical and technological integration.

Similar conclusions are drawn by Van Niekerk and Rudman [24] who notice that adopting IoT as part of business operations could generate value through integration and enhanced information quality by collecting data in real-time. The authors identify that 
financial information retains its characteristics of validity, accuracy, completeness, and timeliness when IoT is deployed. The identified risks for financial information concerned data integrity, confidentiality, authenticity, network availability, and semantic technology vulnerabilities.

Another research carried out recently by Côrte-Real et al. [14] collects data from 618 European and American firms and analyses the use of IoT and Big Data Analytics (BDA) applications. They conclude that BDA and IoT capabilities create significant value in business processes when supported by a good level of data quality.

The research on accounting information quality is conducted by Wu et al. [25]. The authors claim that IoT could significantly change the existing accounting information systems and improve accounting information quality because of new sources of transactional data. The manual reading and input of data are being replaced by devices armed with sensors, and it is possible to collect and process accounting information with realtime visibility without human interaction. IoT is capable of collecting various types of data, such as physical measurement (length, weight, volume), audio, location. Thus, the financial report would provide much more information than only the monetary measurements as a result of which the users would be able to insert relevant values and perform estimates on their judgments. The researchers demonstrate the opinion that IoT and Blockchain technologies have significant effects in terms of improving the relevance of completeness, neutrality, timeliness, cost-benefit balance of accounting information. According to Roszkowska [26], the automation of the accounting system by using sensors presents many benefits: real-time data, lower labour costs, fewer errors, and possibilities for record manipulation.

IoT is also a subject of interest of professional membership organisations of chartered accountants and students. For instance, the Institute of Chartered Accountants in England and Wales (ICAEW) in partnership with the Shanghai National Accounting Institute and Inspur prepared a report [12] concerning the impact of IoT on accounting. The research sample consists of 211 respondents from Chinese companies of which $20 \%$ use IoT mainly in the manufacturing, finance and IT sector, procurement, supply chain management, process quality improvement, and financial management. According to the respondents, IoT has a positive impact on performance, governance, organisational culture, and management. They indicate the following benefits:

- more accurate and automated transaction processing,

- asset tracking which led to reduced downtime, improved information quality and lower audit costs: automated stock checking, asset location, improved assets analysis,

- improved assets utilisation through developed process and asset sharing,

- cost optimisation through analysis and preventative maintenance,

- improved pricing through better cost data generated and analysed,

- quantified employees through improving health and safety,

- forecasting and budgeting improvements. 
All of the above advantages improve accounting processes and have an impact on better decision making. The report indicates the following risks: cyber security and privacy, building necessary infrastructure, sensor accuracy, data skills shortages. One of the most important legal challenges in this area is the protection of personal data and the violation of privacy.

IoT is an important source of big data characterised by five dimensions (i.e., volume, variety, velocity, veracity, and value) to create actionable insights for sustained value delivery and competitive advantages [6]. Data affluence is a key factor for the powerful rise of the Artificial Intelligence (AI) revolution [27]. Thanks to data generation, it is possible for AI algorithms to find new patterns and classify them based upon predetermined criteria. Furthermore, IoT contributes to sustainable development because it can facilitate multiple enhancements in the product life cycle management for reducing waste and also for making products recyclable [28].

Altuk and Kablan [29] expect that IoT will shorten the process of the data collection, reduce the margin of error, and have an impact on financial statements which depicts the performance of a business organisation. Researchers maintain that IoT heralds a revolution in the accounting and auditing profession, thus professionals and students need to follow its development and master skills. According to Kruskopf et al. [30], timeconsuming tasks will be done by machines, and consequently, professionals will be able to focus on adding more value to their customers. Future demands for accountants comprise hard, technical skills: basics of coding, data visualisation, data warehouse management, and understanding the capabilities of the software. Hatane et al. [31] survey 306 accounting students at several universities in Indonesia about their ability to master the IoT device. The analysis indicates the components of IoT skills, namely: information navigation (ability to search on the Internet), social skills (ability of communication, online-interaction), creative skills (ability to create appropriate content to be displayed online), and mobile skills (ability to operate IoT devices using smartphones).

\section{Methodology, research findings, and discussion}

The paper focuses on addressing the following research questions:

What are the benefits of IoT adoption for organisations in the accounting field?

What are the challenges of IoT adoption for organisations in the accounting field?

Given all the above research questions, two research hypotheses were formulated:

H1. IoT adoption enables organisations in the accounting field to automate data processing, perform in-depth analysis thanks to big data from sensors, and enrich their reporting.

$\mathrm{H} 2$. When adopting IoT organisations face challenges in building infrastructure, lack of precise legal provisions, and qualified workforce. 
In this study, semi-structured interview and structured questionnaires are used to generate confirmatory results of the benefits and challenges of IoT in the accounting field. The data for this study were collected in October 2020.

The interview was conducted with the members of the management board of a small Silesian company operating in the road transport sector. Poland is the largest carrier in the EU road transport. According to Eurostat data - road freight transport measurement, in 2018, Polish companies transported 270 million tons of cargo, which accounted for $23 \%$ of the total for the EU [32]. The dominant position of Polish transport companies is mainly driven by high price competitiveness. Wage pressure and recent changes in the legal environment (e.g., the mobility package for road transport - new EU rules, which intend to end distortion of competition in the transport sector) forced the company to improve effectiveness and efficiency by adopting the Logistics 4.0 solutions. The process was twofold. First, the board of management decided to replace part of the fleet with new Scania vehicles with pre-installed communicator telematics units, which consistently collected, saved, sent, received information for analysis and presentation on the Scania Fleet Management portal and in the monitoring reports. Second, a remote monitoring system for fuel tanks was employed. The two solutions provided the managers with 24-hour access to key details and reports on vehicles, fleet position, and fuel usage. The managers particularly praised the Driver Evaluation reports, which checked drivers' driving style and through improving it, the company could save fuel and reduce vehicle wear.

On this basis, an incentive system for employees was introduced, consequently, the adoption of IoT - in opinion of the Management Board - significantly increased employee productivity. Next, important functionality was asset management through their localisation and better control as well as automatic inventory checking and generation of warehouse documents. The managers indicated the following benefits in the accounting field: thanks to continuous and enormous data flow in real-time it was possible to perform multi-dimensional financial analysis, improve budgeting and forecasting accuracy, cost planning, and pricing. Then, IoT supported reporting, especially for the statistical office, by providing details on cargo transportation, tonne-kilometres, and environmental impact based on the information on fuel consumption, carbon dioxide, and other emissions. The information obtained from sensors was used in the management report prepared along with the annual financial statement. Third, the adoption of IoT enabled seamless integration with the existing systems. Thanks to data provided by IoT in a standardised format, it was possible to import the data in an electronic form into the accounting information system, earlier paper documents were input manually. Therefore, IoT adoption automated many mundane accounting tasks, eliminated the possibility of errors and limited paper documents, especially in the warehouse area. To summarise, the adoption of IoT in the company improved the quality of financial information and reduced the costs of processing accounting vouchers. 
According to the managers, the role of accountants changed, as the staff instead of entering data and recordkeeping should concentrate on cleaning data up, combining and preparing analysis more comprehensively to facilitate decision making. The informants emphasised that accountants should develop data literacy, analytical, and coding skills. Furthermore, the managers specified some challenges and risks related to IoT adoption in the company. The most important ones were high investment costs and insufficient mechanisms for financing the implementation of innovations and a lack of tax incentives. Besides, some employees were sceptical and resistant to changes as they were afraid of loss of privacy and closer supervision. The managers complained about a lack of precise provisions regarding the use of IoT. Overall, in the opinion of the managers, the benefits outweighed the challenges, and thanks to the implementation of IoT and better decision making, business performance increased. The above example shows that IoT is also available for SMEs and adopting new technologies provides a level playing field with large companies.

Based on the literature review and the interview outcomes, a list of benefits and challenges used in the questionnaire is presented in Table 1.

Table 1. Benefits and challenges of IoT adoption

\begin{tabular}{|l|l|l|l|}
\hline \multicolumn{2}{|c|}{ Benefits (B) } & \multicolumn{2}{c|}{ Challenges (R) } \\
\hline B1 & growth of employee productivity & R1 & $\begin{array}{l}\text { lack of precise legal provisions regarding } \\
\text { the implementation and use of IoT }\end{array}$ \\
\hline B2 & $\begin{array}{l}\text { automation of entering and processing } \\
\text { of transactions }\end{array}$ & R2 & $\begin{array}{l}\text { technical and technological integration, } \\
\text { including solutions from multiple vendors }\end{array}$ \\
\hline B3 & creating new business models & R3 & workers' resistance to change and innovation \\
\hline B4 & $\begin{array}{l}\text { improved asset management through their } \\
\text { location, control and better use }\end{array}$ & R4 & $\begin{array}{l}\text { shortage of employees with knowledge } \\
\text { and skillsin the field of IoT on the market }\end{array}$ \\
\hline B5 & $\begin{array}{l}\text { optimisation of costs through their analysis } \\
\text { and better absorption (division of indirect costs } \\
\text { per product unit), support of management } \\
\text { accounting tools, such as activity costing, } \\
\text { target cost accounting }\end{array}$ & R5 & $\begin{array}{l}\text { compatibility between sensors, networks } \\
\text { and applications from different technologies } \\
\text { and vendors }\end{array}$ \\
\hline B6 & $\begin{array}{l}\text { improved quality of financial information } \\
\text { by accessing more detailed data in real-time }\end{array}$ & R66 & $\begin{array}{l}\text { lack of knowledge about the benefits of IoT } \\
\text { implementation }\end{array}$ \\
\hline B7 & $\begin{array}{l}\text { drilling down on data and performing } \\
\text { multi-dimensional data analyses based on } \\
\text { the acquisition of large amounts of data } \\
\text { (big data) }\end{array}$ & R7 & $\begin{array}{l}\text { loss of privacy and confidentiality through } \\
\text { access and processing of personal data }\end{array}$ \\
\hline B8 & $\begin{array}{l}\text { enrichment of financial reporting } \\
\text { by providing additional non-financial } \\
\text { information acquired through sensors }\end{array}$ & R8 & $\begin{array}{l}\text { reluctance to and distrust } \\
\text { of modern technologies }\end{array}$ \\
\hline B9 & $\begin{array}{l}\text { convenient tool that allows access to data } \\
\text { without time and location restrictions } \\
\text { through cloud computing }\end{array}$ & R9 & cyber security threats \\
\hline
\end{tabular}


Table 1. Benefits and challenges of IoT adoption

\begin{tabular}{|l|l|l|l|}
\hline \multicolumn{2}{|c|}{ Benefits (B) } & \multicolumn{2}{|c|}{ Challenges (R) } \\
\hline B10 & $\begin{array}{l}\text { easier audit of financial statements } \\
\text { in real-time through process automation }\end{array}$ & R10 & $\begin{array}{l}\text { building infrastructure } \\
\text { necessary to implement IoT }\end{array}$ \\
\hline B11 & reduction of employment & R11 & $\begin{array}{l}\text { doubts about the accuracy of sensors } \\
\text { used in IoT solutions }\end{array}$ \\
\hline B12 & $\begin{array}{l}\text { automatic inventory, ordering and generation } \\
\text { of warehouse documents and better use } \\
\text { of resources }\end{array}$ & R12 & $\begin{array}{l}\text { contributing to micro-management } \\
\text { characterised by a high degree of observation } \\
\text { and control of the work of subordinates, } \\
\text { which limits the freedom of employees }\end{array}$ \\
\hline B13 & $\begin{array}{l}\text { modification of architecture of accounting } \\
\text { information systems by changing the source } \\
\text { of input data }\end{array}$ & R13 & $\begin{array}{l}\text { demand barriers to the development } \\
\text { of companies in the IoT sector }\end{array}$ \\
\hline B14 & $\begin{array}{l}\text { changes in the accounting profession } \\
\text { by the requirement of knowledge and skills } \\
\text { in computer science, data and information } \\
\text { flow in the enterprise }\end{array}$ & R14 & $\begin{array}{l}\text { lack of support from public institutions } \\
\text { for IoT market development }\end{array}$ \\
\hline B15 & $\begin{array}{l}\text { improvement of the budgeting, forecasting } \\
\text { and product pricing processes }\end{array}$ & R15 & ethical use of IoT technology and systems \\
\hline B16 & $\begin{array}{l}\text { contribution to better risk management } \\
\text { by eliminating production downtime }\end{array}$ & R16 & $\begin{array}{l}\text { threats and vulnerabilities in devices } \\
\text { and IoT networks }\end{array}$ \\
\hline B17 & $\begin{array}{l}\text { improvement of decision making } \\
\text { and thus growth of efficiency through access } \\
\text { to large amounts of data in real-time }\end{array}$ & R17 & $\begin{array}{l}\text { fear of losing a job as a result } \\
\text { of progressing automation }\end{array}$ \\
\hline B18 & $\begin{array}{l}\text { contribution to the optimisation } \\
\text { of the supply chain }\end{array}$ & R18 & $\begin{array}{l}\text { unavailability of financial resources to support } \\
\text { the implementation and maintenance of IoT }\end{array}$ \\
\hline B19 & $\begin{array}{l}\text { levelopment and offer of new categories } \\
\text { of products and services to customers } \\
\text { and weak authentication system } \\
\text { to protect the data being transferred } \\
\text { via IoT devices }\end{array}$ \\
\hline B20 & $\begin{array}{l}\text { improvement of user experience } \\
\text { locating an internet connection in a public space } \\
\text { to which many users have access }\end{array}$ \\
\hline
\end{tabular}

The questionnaire was hosted on the Social Media, a group devoted to accounting, through web-based survey development tools and was distributed to 22084 accounting professionals and students, using a probability sampling technique. The final sample consisted of 151 respondents, so the response rate was $0.68 \%$. The items of the questionnaire were developed using a five-level Likert scale (from $1=$ strongly disagree to $5=$ strongly agree) to indicate the level of respondents' agreement to a series of questions regarding benefits and challenges of IoT adoption. The questionnaire items consisted of demographics, such as: gender, age, education and status, and place of employment. The detailed characteristics of the respondents' demographics are presented in Table 2. 
Table 2. Distribution of the sample members

\begin{tabular}{|l|l|c|c|}
\hline \multirow{2}{*}{ Characteristics } & \multirow{2}{*}{ Answer } & \multicolumn{2}{c|}{ Frequency } \\
\cline { 3 - 4 } & & No. of answers & Per cent \\
\hline \multirow{3}{*}{ Gender } & male & 28 & 18.5 \\
\cline { 2 - 4 } & female & 123 & 81.5 \\
\hline \multirow{4}{*}{ Age } & up to 20 years & 17 & 11.3 \\
\cline { 2 - 4 } & $21-30$ years & 98 & 64.9 \\
\cline { 2 - 4 } & $31-45$ years & 29 & 19.2 \\
\cline { 2 - 4 } & above 46 years & 7 & 4.6 \\
\hline \multirow{3}{*}{ Education level } & middle & 80 & 53.0 \\
\cline { 2 - 4 } & high & 71 & 47.0 \\
\hline \multirow{4}{*}{$\begin{array}{l}\text { Slace } \\
\text { of employs }\end{array}$} & unemployed student & 43 & 28.5 \\
\cline { 2 - 4 } & employed student & 67 & 44.4 \\
\cline { 2 - 4 } & specialist & 41 & 27.1 \\
\cline { 2 - 4 } & unemployed & 43 & 28.5 \\
\cline { 2 - 4 } & micro enterprise (1-10 employees) & 26 & 17.2 \\
\cline { 2 - 4 } & small enterprise (10-49 employees) & 25 & 16.6 \\
\cline { 2 - 4 } & medium-sized enterprise (50-249 employees) & 22 & 14.6 \\
\cline { 2 - 4 } & large enterprise (250 employees and more) & 35 & 23.1 \\
\hline
\end{tabular}

The next question concerned the level of knowledge of IoT technology. Table 3 displays the results - only $49.6 \%$ of the respondents declared knowledge of IoT.

Table 3. The level of respondents' knowledge of IoT

\begin{tabular}{|l|c|c|}
\hline \multirow{2}{*}{ Attitude to IoT technology } & \multicolumn{2}{|c|}{ Frequency } \\
\cline { 2 - 3 } & No. of answers & Per cent \\
\hline Strongly agree (5) & 20 & 13.2 \\
\hline Agree (4) & 55 & 36.4 \\
\hline Neither agree nor disagree (3) & 21 & 13.9 \\
\hline Disagree (2) & 37 & 24.5 \\
\hline Strongly disagree (1) & 18 & 11.9 \\
\hline
\end{tabular}

The comparison among groups of responses in terms of status (unemployed student, employed students and specialists) was performed. The Kruskal-Wallis test revealed that status had no significant effect on knowledge level $(\mathrm{H} 2=2.349, p \geq 0.05)$.

The subsequent items of the questionnaire measured the users' attitudes to rate the degree to which they agree or disagree with a statement towards benefits and challenges of IoT implementation, especially in the accounting field of organisations. The items were also developed using a 5-level Likert scale. The study employed the quantitative research methodology with the support of the SPSS software. First, Cronbach's alpha coefficient was calculated to provide an overall assessment of the measure's reliability and internal consistency of the entire scale. The high value of the coefficient (0.948) indicated that the scale had high reliability and was useful in the research. 
Next, the frequencies and volatility measures were calculated. The statistics for benefits are presented in Table 4 and for risks and challenges in Table 5, respectively, including responses to the items of the questionnaire and ranks using the average.

Table 4. Frequency of answers and descriptive statistics for benefits

\begin{tabular}{|c|c|c|c|c|c|c|c|c|c|c|}
\hline \multirow{2}{*}{ Benefit } & \multicolumn{5}{|c|}{ Frequency } & \multirow{2}{*}{ Mean } & $\begin{array}{c}\text { Std. } \\
\text { deviation }\end{array}$ & Skewness & Sum & Rank \\
\cline { 2 - 5 } & 1 & 2 & 3 & 4 & 5 & & 0.768 & -0.029 & 557 & 15 \\
\hline B1 & 0 & 7 & 54 & 69 & 21 & 3.69 & 0.819 & -0.356 & 597 & 3 \\
\hline B2 & 0 & 6 & 36 & 68 & 41 & 3.95 & -0.298 & 583 & 6 \\
\hline B3 & 1 & 2 & 44 & 74 & 30 & 3.86 & 0.766 & -0.294 & 583 & 8 \\
\hline B4 & 1 & 4 & 46 & 64 & 36 & 3.86 & 0.833 & 0.125 & 571 & 12 \\
\hline B5 & 0 & 4 & 58 & 56 & 33 & 3.78 & 0.816 & -0.384 & 588 & 5 \\
\hline B6 & 1 & 6 & 43 & 59 & 42 & 3.89 & 0.881 & -0.592 & 601 & 1 \\
\hline B7 & 2 & 3 & 40 & 57 & 49 & 3.98 & 0.890 & -0.336 & 591 & 4 \\
\hline B8 & 1 & 4 & 45 & 58 & 43 & 3.91 & 0.864 & -0.207 & 600 & 2 \\
\hline B9 & 0 & 3 & 39 & 68 & 41 & 3.97 & 0.783 & -0.218 & 583 & 7 \\
\hline B10 & 1 & 2 & 48 & 66 & 34 & 3.86 & 0.800 & -0.101 & 504 & 20 \\
\hline B11 & 6 & 18 & 67 & 39 & 21 & 3.34 & 0.993 & -0.101 & 572 & 11 \\
\hline B12 & 1 & 2 & 54 & 65 & 29 & 3.79 & 0.788 & 0.039 & 549 & 17 \\
\hline B13 & 1 & 8 & 64 & 50 & 28 & 3.64 & 0.868 & -0.101 & 564 & 14 \\
\hline B14 & 1 & 8 & 57 & 49 & 36 & 3.74 & 0.907 & -0.043 & 545 & 19 \\
\hline B15 & 1 & 9 & 61 & 57 & 23 & 3.61 & 0.840 & -0.133 & 547 & 18 \\
\hline B16 & 2 & 7 & 62 & 55 & 25 & 3.62 & 0.862 & -0.293 & 573 & 10 \\
\hline B17 & 1 & 6 & 47 & 66 & 31 & 3.79 & 0.835 & -0.113 & 567 & 13 \\
\hline B18 & 1 & 6 & 56 & 54 & 34 & 3.75 & 0.872 & -0.218 & 580 & 9 \\
\hline B19 & 1 & 5 & 51 & 54 & 40 & 3.84 & 0.880 & -293 & 550 & 16 \\
\hline B20 & 3 & 5 & 60 & 58 & 25 & 3.64 & 0.867 & & & \\
\hline
\end{tabular}

Numbering frequencies as in Table 3.

The top three benefits of IoT adoption, as perceived by the respondents, were: providing large amounts of data (big data), which enabled drilling down on data and performing multi-dimensional data analyses (mean is 3.98), the second top-ranked benefit was the access to data through cloud-computing without the time and location restrictions (3.97), and the third benefit was the automation of entering and processing the data (3.95). Conversely, the three least potential benefits were: personnel reduction (3.34), improvement of budgeting, forecasting and product pricing processes (3.61), and contribution to better risk management by eliminating production downtime (3.62).

As far as risks and challenges were concerned, the respondents most often indicated cyber security threats (mean is 3.97), threats and vulnerabilities in devices and IoT networks (3.89), loss of privacy and confidentiality through access to and processing of personal data (3.83). On the other hand, the respondents least often indicated demand barriers (3.45), doubts about the accuracy of sensors (3.52), and contribution to micromanagement (3.63). 
Table 5. Frequency of answers and descriptive statistics for challenges

\begin{tabular}{|c|c|c|c|c|c|c|c|c|c|c|}
\hline \multirow{2}{*}{ Challenge } & \multicolumn{5}{|c|}{ Frequency } & \multirow{2}{*}{ Mean } & \multirow{2}{*}{$\begin{array}{c}\text { Std. } \\
\text { deviation }\end{array}$} & \multirow{2}{*}{ Skewness } & \multirow{2}{*}{ Sum } & \multirow{2}{*}{ Rank } \\
\hline & \begin{tabular}{|l|}
1 \\
\end{tabular} & 2 & 3 & 4 & 5 & & & & & \\
\hline R1 & 1 & 7 & 49 & 61 & 33 & 3.78 & 0.863 & -0.253 & 571 & 5 \\
\hline $\mathrm{R} 2$ & 2 & 6 & 49 & 75 & 19 & 3.68 & 0.795 & -0.495 & 556 & 13 \\
\hline R3 & 0 & 11 & 59 & 35 & 46 & 3.77 & 0.969 & -0.009 & 569 & 6 \\
\hline $\mathrm{R} 4$ & 2 & 11 & 39 & 58 & 41 & 3.83 & 0.958 & -0.525 & 578 & 4 \\
\hline R5 & 1 & 9 & 50 & 67 & 24 & 3.69 & 0.834 & -0.268 & 557 & 11 \\
\hline R6 & 2 & 8 & 55 & 58 & 28 & 3.68 & 0.884 & -0.253 & 555 & 14 \\
\hline R7 & 2 & 12 & 45 & 43 & 49 & 3.83 & 1.018 & -0.415 & 578 & 3 \\
\hline $\mathrm{R} 8$ & 5 & 10 & 49 & 49 & 38 & 3.70 & 1.026 & -0.483 & 558 & 10 \\
\hline R9 & 0 & 7 & 42 & 51 & 51 & 3.97 & 0.898 & -0.327 & 599 & 1 \\
\hline R10 & 2 & 12 & 50 & 54 & 33 & 3.69 & 0.946 & -0.295 & 557 & 12 \\
\hline $\mathrm{R} 11$ & 2 & 12 & 61 & 57 & 19 & 3.52 & 0.863 & -0.167 & 532 & 19 \\
\hline R12 & 2 & 9 & 61 & 50 & 29 & 3.63 & 0.906 & -0.120 & 548 & 18 \\
\hline R13 & 3 & 13 & 66 & 51 & 18 & 3.45 & 0.885 & -0.140 & 521 & 20 \\
\hline R14 & 1 & 7 & 63 & 51 & 29 & 3.66 & 0.863 & 0.022 & 553 & 15 \\
\hline $\mathrm{R} 15$ & 1 & 9 & 58 & 57 & 26 & 3.65 & 0.858 & -0.088 & 551 & 17 \\
\hline R16 & 0 & 5 & 45 & 63 & 38 & 3.89 & 0.821 & -0.154 & 587 & 2 \\
\hline R17 & 4 & 14 & 48 & 38 & 47 & 3.73 & 1.083 & -0.398 & 563 & 7 \\
\hline R18 & 1 & 14 & 51 & 55 & 30 & 3.66 & 0.924 & -0.184 & 552 & 16 \\
\hline R19 & 0 & 10 & 54 & 59 & 28 & 3.70 & 0.848 & -0.034 & 558 & 9 \\
\hline R20 & 0 & 11 & 50 & 61 & 29 & 3.72 & 0.859 & -0.116 & 561 & 8 \\
\hline
\end{tabular}

Numbering frequencies as in Table 3.

For further analysis, the explanatory factor analysis with the extraction method, principal axis factoring and rotation method: Promax with Kaiser was performed to group similar variables into dimensions for each of the items used within the two adopted constructs: benefits and challenges. The results of two tests Kaiser-Meyer -Olkin measure of sampling adequacy (for benefits 0.934, for challenges 0.903 ) and Bartlett's test of sphericity confirmed the suitability of the data for factor detection $(p<0.001)$.

The Pattern Matrix (Table 6) displays the items and factor loadings for the rotated factors, with loadings less than 0.5 omitted to improve clarity for benefits and Table 7 for challenges, respectively. Only three factors with eigenvalues greater than 1 account for most of the variation for benefits and four factors for challenges, respectively.

The first factor, which accounts for $51.283 \%$ of the variance, has strong loading on the benefit related to the possibility to perform in-depth financial analysis and reports (B7) and enriched financial reports (B8) due to a continuous flow of big data from IoT sensors as well as assets management and control (B4) and automation of data processing (B2). The results confirm $\mathrm{H} 1$ assuming that automation of data processing, performing in-depth analysis and enriched reporting are the main benefits of IoT adoption. 
Table 6. Pattern matrix for benefits

\begin{tabular}{|l|c|c|c|}
\hline \multirow{2}{*}{ Challenge } & \multicolumn{3}{c|}{ Factor } \\
\cline { 2 - 4 } & 1 & 2 & 3 \\
\hline B1 & 0.618 & & \\
\hline B2 & 0.698 & & \\
\hline B3 & 0.744 & & \\
\hline B4 & 0.778 & & \\
\hline B5 & 0.680 & & \\
\hline B6 & 0.629 & & \\
\hline B7 & 0.884 & & \\
\hline B8 & 0.847 & & \\
\hline B9 & 0.654 & & \\
\hline B10 & 0.580 & & \\
\hline B15 & & 0.500 & 0.521 \\
\hline B16 & & 0.751 & \\
\hline B17 & & 0.591 & \\
\hline B18 & & 0.737 & \\
\hline B19 & & 0.711 & \\
\hline B20 & & 0.765 & \\
\hline Variance explained & 10.257 & 1.542 & 1.007 \\
\hline Per cent of variance explained & 51.283 & 7.711 & 5.036 \\
\hline Cumulative variance explained, \% & 51.283 & 58.994 & 64.030 \\
\hline
\end{tabular}

Table 7. Pattern matrix for challenges

\begin{tabular}{|l|c|c|c|c|}
\hline \multirow{2}{*}{ Challenge } & \multicolumn{4}{|c|}{ Factor } \\
\cline { 2 - 5 } & 1 & 2 & 3 & 4 \\
\hline R1 & & & 0.585 & \\
\hline R2 & & & 0.692 & \\
\hline R4 & & & & 0.677 \\
\hline R7 & & 0.649 & & \\
\hline R8 & & 0.690 & & \\
\hline R9 & & 0.502 & & \\
\hline R10 & 0.656 & & & \\
\hline R11 & 0.509 & & & \\
\hline R12 & 0.504 & & & \\
\hline R13 & 0.588 & & & \\
\hline R14 & & & 0.556 & \\
\hline R15 & & & & \\
\hline R16 & & 0.543 & & \\
\hline R17 & 0.589 & & & \\
\hline R18 & 0.644 & & & \\
\hline R20 & 0.625 & & & \\
\hline Variance explained & 8.044 & 1.446 & 1.253 & 1.086 \\
\hline Per cent of variance explained & 40.220 & 7.230 & 6.263 & 5.432 \\
\hline Cumulative variance explained, \% & 40.220 & 47.451 & 53.714 & 59.146 \\
\hline
\end{tabular}


The second factor, which explained $7.711 \%$ of the variance has strong loadings on the benefit related to better user experience (B20), optimisation of the supply chain (B18), risk management by eliminating production downtime (B16) and creation of new products (B19). The third factor accounted for $5.036 \%$ of the variance and was correlated with the second factor, which had strong loading on the benefit regarding the improvement of budgeting, forecasting and pricing (B15).

For challenges, the first factor, which accounted for $40.220 \%$ of the variance, was related to the infrastructure aspects. Specifically, it was paramount to build the necessary infrastructure (R10) and gain financing to be able to adapt IoT technology (R18). The second factor, which explained $7.230 \%$ of the variance, was related to the threats, mainly cyber security (R9) and loss of privacy (R7). The next factor represented legal support accounted for $6.263 \%$ of the variance, and had strong loadings on insufficient legal provision for implementing and using IoT (R1). The last factor explained 5.432\% of the variance and had strong loadings on undersupply of the qualified workforce (R4). The results confirm $\mathrm{H} 2$, assuming that challenges comprise building infrastructure, lack of legal provisions and qualified workforce.

As based on the research outcome, it is possible to answer the research questions and confirm the hypotheses. The results of both the interview and the questionnaires showed that the most basic accounting benefits arising from IoT adoption in organisations are improvement of accounting and reporting, especially in data quality, automation of transaction processing and asset management. IoT technology ensures that accounting information meets the quality criteria, such as the reliability - faithful representation (replacing human eyesight by sensors ensures accurate measurement and completeness), timeliness (real-time information due to broadcast timing), verifiability (audit trails through automatic logging, gateway timestamp, DateTime serialisation format). One of the opportunities of IoT, most often indicated by the respondents, was drilling down the data to perform analysis. A better understanding of the nature and behaviour of costs enables organisations to shift to modern cost accounting methods (such as absorption costing, standard costing, activity-based costing, target costing) which the main purpose is to provide required information to management on the effectiveness of certain products, projects, activities, consumers, responsibility centres, focused on cost rationalisation and cost reduction [33]. In-depth data analysis and asset management impact on cost reduction, for instance in the logistics sector - tracing vehicles to optimise route taking, maximise both direction loads and improvement of driving style which enable organisations to save up to $10 \%$ in fuel [34]. For finance professionals, IoT must provide additional data that can assist reporting and also enrich financial statements to add more value to organisations. In asset control and management, contactless RFID tag technology can be employed, for example, a RFID Navigator system connected to the enterprise resource planning (ERP) solution collects accurate and available real-time information about where the tagged object is or is moving. As the world is changing, 
accountants need to adapt and develop skills to become data specialists and be more tech-savvy.

A major concern for IoT, according to the respondents, is related to the building and financing of infrastructure. This factor explained $40.220 \%$ of the variance. As the light at the end of the tunnel can be perceived the initiative of the Ministry of Digital Affairs which, in 2018, established the Working Group for the Internet of Things intending to identify actions necessary to enable development and common use of this technology. In 2019, the members of the group prepared a report about the institutional and legal status, the business environment of the IoT industry in Poland and since then they have been focusing on developing projects, supporting its common use in areas: smart cities and buildings, agriculture, healthcare system, transport, standardisation and legislation.

From 2021, entrepreneurs have gained another incentive to modernise production processes using innovative technologies. New tax relief for robotisation consists of an additional deduction of $50 \%$ of eligible investment costs from the tax base and applies to all companies regardless of their size. Another challenge is related to cyber security, e.g., hacking attacks on the vital IoT infrastructure. The unconscious use, lack of strong encryption and weak authentication system and device updates have increased cyber security risks and access to malicious applications to IoT systems' sensitive data, therefore, it is imperative to employ professionals to overcome those threats and develop comprehensive security policies to protect assets and ensure business stability [35]. Furthermore, the inability to anonymise data and non-transparent operations of IoT devices with an obligation to provide users' information about the processing of their data contribute to the increasing threats to privacy. Finally, the respondents indicated shortages of qualified staff in the area of new technologies and data analysis.

\section{Conclusion}

IoT technology boosts the global economy and revolutionises a lot of business aspects, including accounting. The main benefits of IoT adoption include data processing automation which changes accounting information systems. According to the respondents, who were accounting professionals and students, the big data provided by sensors enable an organisation to perform enhanced analysis, which could improve efficiency. While for the managers, the most important benefit was an increase in employee productivity and asset management. On the other hand, costs related to the adoption of a new technology, imprecise legal regulations and shortage of qualified personnel, including accountants, are perceived as challenges. The results indicated that only $49.6 \%$ of the respondents declared knowledge of IoT. It can be concluded that accounting professionals and students should follow the emerging technologies as well as master technical and analytical skills. 
This work provides a first discussion on the implications of IoT use in the accounting field. The research findings contribute to the literature in several ways. First, they provide practitioners with the benefits and challenges of IoT adoption and they can therefore support managers to deploy new technology in their organisations. Second, they expand the limited literature in the field of accounting. Future research may explore the role of IoT technology in modern cost accounting methods. However, the findings have to be seen in light of some limitations. The main one is that the interview was conducted with the managers from only one company and a single sector: road transport. The next limitation concerns the fact that this study focuses on respondents from Poland.

\section{References}

[1] NutTALl N., The Evolution of IoT and its impact on adopters and technology providers. A Gartner Trend Insight Report, 2018, 11.

[2] Whitmore A., Agarwal A., Da Xu L., The Internet of Things. A survey of topics and trends, Inf. Syst. Front., 2015, 17, 261-274, DOI: 10.1007/s10796-014-9489-2.

[3] Chen T., Barbarossa S., Wang X., Giannakis G.B., Zhang Z.L., Learning and management for internet of things: Accounting for adaptivity and scalability, Proc IEEE 2019, 107, 778-96, DOI: 10.1109 /JPROC.2019.2896243.

[4] RaYes A., Salam S., Internet of Things From Hype to Reality, Springer, 2018.

[5] HoLst A., IoT connected devices worldwide 2019-2030, Statista 2021, https://www.statista.com/statistics /1183457/iot-connected-devices-worldwide/

[6] Lin C.R., GeRla M., Adaptive clustering for mobile wireless networks, IEEE J. Sel. Areas Comm., 1997, 15, 1265-1275, DOI: 10.1109/49.622910.

[7] Goasduff L., What Is Industrie 4.0 and What Should CIOs Do About It, Gartner, Egham, UK, Newsroom, Press Releases, 2015.

[8] Winkelhaus S., Grosse E.H., Logistics 4.0. A systematic review towards a new logistics system, Int. J. Prod. Res., 2020, 58, 18-43, DOI: 10.1080/00207543.2019.1612964.

[9] Culot G., Nassimbeni G., Orzes G., Sartor M., Behind the definition of Industry 4.0. Analysis and open questions, Int. J. Prod. Econ., 2020, 226, 107617, DOI: 10.1016/j.ijpe.2020.107617.

[10] Kagermann H., Wahlster W., Helbig J., Securing the future of German manufacturing industry. Recommendations for implementing the strategic initiative Industrie 4.0, Final Report of the Industrie 4.0 Working Group, National Academy of Science and Engineering, Frankfurt/Main 2013.

[11] Al-FuqAha A., GuIZANi M., Mohammadi M., AledHARi M., AYyash M., Internet of Things. A survey on enabling technologies, protocols, and applications, IEEE Commun. Surv. Tut., 2015, 17, 2347-2376, DOI: 10.1109/COMST.2015.2444095.

[12] The internet of things and accounting: lessons from China, Institute of Chartered Accountants in England and Wales, ICAEW Thought Leadership Business And Management Faculty, London 2019.

[13] EY Law Report Compass Law and Innovation. 2020 challenges, London 2020.

[14] CôRTE-REal N., Ruivo P., Oliveira T., Leveraging internet of things and big data analytics initiatives in European and American firms: Is data quality a way to extract business value?, Inf. Manage., 2020, 57, DOI: 10.1016/j.im.2019.01.003.

[15] RugKhaPAn N.T., MuRRAY M.J., Songdo IBD (International Business District): experimental prototype for the city of tomorrow?, Int. Plan. Stud., 2019, 24, 272-292, DOI: 10.1080/13563475.2019.1650725. 
[16] Sahu A.K., SAhU A.K., Sahu N.K., A review on the research growth of Industry 4.0, Int. J. Bus. Anal., 2020, 7, 77-97, DOI: 10.4018/ijban.2020010105.

[17] The Act on Value Added Tax of 15 March 2019 and the Act on Trade Metrology Law, Journal of Laws 2019, item 675.

[18] AslanertiK B.E., YardimCi B., A comprehensive framework for Accounting 4.0. Implications of Industry 4.0 in Digital Era, 2019, p. 549-63, DOI: 10.1007/978-3-030-25275-527.

[19] Brous P., JANSSEN M., HERDER P., The dual effects of the Internet of Things (IoT): A systematic review of the benefits and risks of IoT adoption by organizations, Int. J. Inf. Manage., 2020, 51, 101952, DOI: 10.1016/j.ijinfomgt.2019.05.008.

[20] Hall J.A., Accounting Information Systems, 2nd Ed., South-Western College Publishing, 1998.

[21] International Accounting Standards Board. Conceptual Framework for Financial Reporting, The International Financial Reporting Standards Foundation, USA, Delaware, 2018.

[22] The Act of Accounting, Journal of Laws of 2021, item 217, n.d.

[23] Haddud A., DesouZA A., KHARE A., LEE H., Examining potential benefits and challenges associated with the Internet of Things integration in supply chains, J. Manuf. Technol. Manage., 2017, 28, 1055-1085, DOI: 10.1108/JMTM-05-2017-0094.

[24] VAn NieKerk A., Rudman R., Risks, controls and governance associated with internet of things technologies on accounting information, South African J. Acc. Audit. Res., 2019, 21, 15-30.

[25] Wu J., Xiong F., Li C., Application of Internet of Things and blockchain technologies to improve accounting information quality, IEEE Access, 2019, 7, 100090-100098, DOI: 10.1109/ACCESS. 2019.2930637.

[26] RoszKowska P., Fintech in Financial Reporting and Audit for Fraud Prevention and Safeguarding Equity Investments, SSRN Electr. J., 2020, 17 (2), 164-196, DOI: 10.2139/ssrn.3679816.

[27] NAQvi A.S., Artificial Intelligence for Audit, Forensic Accounting, and Valuation: A Strategic Perspective, Wiley, 2020.

[28] Tiwari K., Khan M.S., Sustainability accounting and reporting in the industry 4.0, J. Clean. Prod. 2020, 258, 120783, DOI: 10.1016/j.jclepro.2020.120783.

[29] Altuk V.E., Kablan A., A critical approach to accounting in the Digital Era: Assessment of the impacts of Industry 4.0 on financials, [In:] U. Hacioglu (Ed.), Digtal Business Strategies in Blockchain Ecosystems, Springer, 2020.

[30] Kruskopf S., Lobbas C., Meinander H., Söderling K., Martikainen M., Lehner O., Digital accounting and the human factor. Theory and practice, ACRN J. Fin. Risk Persp., 2020, 9, 78-89, DOI: 10.35944/JOFRP.2020.9.1.006.

[31] Hatane S.E., Johari I.V.D., Valencia J., Prayugo L.E., The Acceptance of Accounting Students on the Use of Internet of Things, Proc. Int. Conf. on Tourism, Economics, Accounting, and Social Science, Springer, 2019, 103, DOI: 10.2991/teams-19.2019.44.

[32] MroczeK W., Poland, the largest haulier in EU road transport 2020, https://www.obserwator finansowy.pl/bez-kategorii/rotator/polska-najwiekszym-przewoznikiem-w-transporcie-drogowym-ue/

[33] PerčEvić H., Hladika M., Movement from Traditional to Modern Cost Accounting Methods in Manufacturing Companies (*), Muhasebe ve Finans Tarihi Araştırmaları Derg, 2016, 155-180.

[34] Scania. Scania Fleet Management Portal, https://fmpnextgen-opt.scania.com/

[35] Tawalbeh L., Muheidat F., TAwalbeh M., Quwaider M., IoT privacy and security: Challenges and solutions, Appl. Sci., 2020, 10 (12), 4102, DOI: 10.3390/APP10124102. 